\title{
THE EFFECT OF MULTIPLE PROCESSING OF POLYPROPYLENE ON SELECTED PROPERTIES OF INJECTION MOULDED PARTS
}

\author{
Karolina Głogowska', Janusz W. Sikora', Ludmila Dulebová² \\ 1 Lublin University of Technology, Department of Polymer Processing, Nadbystrzycka 36, 20-618 Lublin, \\ Poland, e-mail: k.glogowska@pollub.pl \\ 2 Technical University of Kosice, Katedra strojárskych technológií a materiálov, Mäsiarska 74, 04001 Košice, \\ Slovakia, e-mail: ludmila.dulebova@tuke.sk
}

Received: 2016.06 .16 Accepted: 2016.09.08 Published: 2016.12.01

\begin{abstract}
An injection moulding machine was used to produce injection moulded parts from polypropylene under invariant injection moulding conditions. Part of the injection mouldings were shredded and re-processed up to fifteen times. The mouldings and the shredded plastic were tested for selected strength properties: Young's modulus, maximum tensile stress, breaking stress, strain at maximum stress, strain at break, Shore hardness, impact strength, mass flow rate, and longitudinal and transverse shrinkage. Relevant relationships were identified and conclusions were drawn on the basis of the data obtained.
\end{abstract}

Keywords: strength test, polypropylene, hardness, impact strength, injection moulding.

\section{INTRODUCTION}

Continuous increase in market demand for polymer materials results in continued development of new, and improvement of existing, material recycling methods, which are among the most effective ways of eliminating the negative effects of used polymer materials on the environment $[6,7,9,19]$. However, recycling can change the properties of such materials, including their rheological, mechanical, thermal, chemical, and visual characteristics $[1,5,12,13,14]$. Many research centres conduct studies aimed at determining the impact of multiple processing of polymers, most frequently extrusion or injection moulding, of polymers on their processing properties and the functional properties of products obtained from these materials $[4,16,18]$.

In study [11], PA6 was injection moulded six times to test the effect of multiple processing on its physical-and-mechanical properties as well as its morphology and to determine the maximum number of injection moulding cycles which did not lead to a significant loss of properties. The largest number of PA processing cycles was reported in study [17], in which the original PA6 was injection moulded 16 times; each time its mechanical and rheological properties were tested as a function of number of processing cycles. In [2, 3], polypropylene was extruded 19 times, and its impact strength, basic static tensile strength properties such as tensile strength and stress at break, as well as its melt flow rate and viscosity were determined after each cycle. Studies of rheological and mechanical properties of a PP/PS blend showed that five-fold processing caused changes in the rheological properties tested, but without causing significant changes in mechanical properties [10]. It was also shown that the use of different temperatures of measurement of the investigated strength properties of a PP/PS blend did not have a negative effect on the shape of the curve of these properties versus number of processing cycles [8]. In another publication [15], it was determined on the basis of hardness tests and the values of Young's mod- 
ulus, yield point and relative elongation that the processes of degradation of polypropylene after five cycles of processing of polypropylene waste did not necessitate changes to injection moulding conditions.

This short review of the literature shows that the problems discussed in this article are known and have been described more or less extensively by various researches, but all these reports concern a specific plastic material, processed a limited number of times using a specific method under specific technological conditions. To the best of our knowledge, there are no studies on PP Moplen RP2380 concerning multiple injection moulding of this polymer under the conditions defined in this work.

\section{GOAL AND EXPERIMENTAL DESIGN}

The aim of the present study was to establish the effect of multiple processing of polypropylene on its selected strength properties determined in a static tensile test, its hardness and impact strength, as well as its melt mass flow rate and its shrinkage defined as a change in the transverse and longitudinal dimensions of the obtained injection moulding product.

For the purposes of the present investigation, a list was drawn of the most important test factors characterizing the process under study. The following test factors were considered:

Direct output factors:

- maximum tensile force $\mathrm{F}_{\mathrm{z}}, \mathrm{N}$,

- breaking force $\mathrm{F}_{\mathrm{r}}, \mathrm{N}$,

- elongation at maximum tensile force $\Delta \mathrm{l}_{\mathrm{z}}, \mathrm{mm}$,

- elongation at break $\Delta \mathrm{l}_{\mathrm{r}}, \mathrm{mm}$,

- hardness $\mathrm{H},{ }^{\circ} \mathrm{ShD}$,

- length of injection moulded part $\mathrm{L}_{\mathrm{w}}, \mathrm{mm}$,

- width of injection moulded part $\mathrm{L}_{\mathrm{p}}, \mathrm{mm}$,

- length of mould cavity $\mathrm{L}_{0}, \mathrm{~mm}$,

- width of mould cavity $\mathrm{B}_{0}, \mathrm{~mm}$,

Indirect output factors:

- maximum tensile stress $\sigma_{z^{\prime}}, \mathrm{MPa}$,

- breaking stress $\sigma_{r}, \mathrm{MPa}$,

- Young's modulus E, MPa,

- strain at maximum stress $\varepsilon_{z}, \%$,

- strain at break $\varepsilon_{\mathrm{r}}, \%$,

- Charpy impact strength $\mathrm{U}, \mathrm{kJ} / \mathrm{m}^{2}$,

- longitudinal shrinkage $\mathrm{S}_{\mathrm{w}}, \%$,

- transverse shrinkage $\mathrm{S}_{\mathrm{w}}, \%$,

- melt flow rate MFR, g/10min.
Variable factors included:

- number of processing cycles run using the injection moulding method (number of injection cycles) 15 .

\section{Constant factors:}

- temperature distribution along the plasticizing system of the injection moulding machine, $200{ }^{\circ} \mathrm{C}, 210{ }^{\circ} \mathrm{C}, 230{ }^{\circ} \mathrm{C}, 250{ }^{\circ} \mathrm{C}$,

- injection mould temperature $\mathrm{t}_{\mathrm{f}}=40^{\circ} \mathrm{C}$,

- duration of an injection moulding cycle $\mathrm{t}_{\mathrm{c}}=34.34 \mathrm{~s}$,

- injection pressure $\mathrm{p}_{\mathrm{w}}=8.5 \mathrm{MPa}$,

- time of injection of polymer into a closed mould cavity $\mathrm{T}_{\mathrm{w}}=2.66 \mathrm{~s}$,

- plasticizing time $\mathrm{T}_{\mathrm{u}}=3.26 \mathrm{~s}$,

- cooling time (in the closed mould cavity) $\mathrm{T}_{\mathrm{c}}=20 \mathrm{~s}$,

- screw peripheral speed $\mathrm{V}=22 \mathrm{~m} / \mathrm{min}$,

- clamping time $\mathrm{T}_{\mathrm{d}}=6 \mathrm{~s}$,

- clamping pressure $\mathrm{p}_{\mathrm{w}}=6 \mathrm{MPa}$,

- melt pressure in the plasticizing system $\mathrm{p}_{\mathrm{t}}=0.5 \mathrm{MPa}$,

- tensile speed $\mathrm{v}=100 \mathrm{~mm} / \mathrm{min}$.

- geometric elements of the plasticizing system and the injection mould,

- rate of cooling of the injection moulded part,

- geometric characteristics of tensile tester grips, the measuring head, the strength testing machine, the plastometer, the durometer, and the Charpy hammer.

Interfering factors:

- voltage $219 \div 241 \mathrm{~V}$,

- relative air humidity: $55 \div 65 \%$,

- ambient temperature $20 \div 24{ }^{\circ} \mathrm{C}$.

It was assumed that the impact of the interfering factors was small and could be neglected because those factors did not affect the results.

\section{MATERIAL}

The study was carried out with polypropylene intended for use in injection moulding applications, sold under the trade name Moplen RP2380 and manufactured by Basell Polyolefins. Moplen RP2380 is a random copolymer for injection moulding with nucleation and antistatic additivation. Moplen RP2380 offers very good flowability and excellent transparency. The main application of Moplen RP2380 is thin walled packaging with a high transparency. Moplen RP2380 has a superior aesthetic appearance and can be processed at signifi- 
Table 1. The basic properties of Morplen RP2380

\begin{tabular}{|l|c|}
\hline Property & Value \\
\hline Standard density at $23^{\circ} \mathrm{C}, \mathrm{kg} / \mathrm{m}^{3}$ & 905 \\
\hline Melt mass flow rate $\left(230^{\circ} \mathrm{C} ; 2,16 \mathrm{~kg}\right), \mathrm{g} / 10 \mathrm{~min}$ & 48 \\
\hline Melt volume flow rate $\left(230^{\circ} \mathrm{C} ; 2,16 \mathrm{~kg}\right), \mathrm{cm}^{3} / 10 \mathrm{~min}$ & 65 \\
\hline Young's modulus, $\mathrm{MPa}$ & 1100 \\
\hline Tensile stress at Yield, $\mathrm{MPa}$ & 29 \\
\hline Tensile strain at Yield, \% & 11 \\
\hline Tensile strain at Break, $\%$ & 50 \\
\hline Charpy notched impact strength at $23^{\circ} \mathrm{C}, \mathrm{kJ} / \mathrm{m}^{2}$ & 4.5 \\
\hline Charpy unnotched impact strength at $23^{\circ} \mathrm{C}, \mathrm{kJ} / \mathrm{m}^{2}$ & 180 \\
\hline Ball indentation hardness $(\mathrm{H} 358 / 30), \mathrm{MPa}$ & 58 \\
\hline Heat deflection temperature, $\mathrm{B}(0.45 \mathrm{MPa}){ }^{\circ} \mathrm{C}$ & 70 \\
\hline Vicat softening temperature, $\left(\mathrm{A} 50\left(50^{\circ} \mathrm{C} / \mathrm{h} 10 \mathrm{~N}\right){ }^{\circ} \mathrm{C}\right.$ & 130 \\
\hline
\end{tabular}

cantly lower temperatures. Moplen RP2380 enables energy savings and improved productivity due to reduced cycle times. Its basic properties, according to the manufacturer's data, are given in Table 1.

\section{TEST SPECIMENS}

Static tensile test specimens, hardness test specimens, and shrinkage test specimens were prepared in accordance with the standards PNEN ISO 527-1: 2012E and PN-EN ISO 527-2: 2012E; all the specimens were fabricated using an Ergotech pro 25-80 injection moulding machine. In accordance with the relevant standard, the specimens were type- 2 specimens with an overall length of $150 \pm 2 \mathrm{~mm}$, a width at narrow portion of $10 \pm 0.5 \mathrm{~mm}$, a thickness of $4 \pm 0.5$ $\mathrm{mm}$ and a measuring section of $50 \pm 0.5 \mathrm{~mm}$. The impact strength test specimens were cut from strength test specimens, and the material for determination of melt mass flow rate was obtained by shredding strength test specimens.

\section{TEST STAND}

The test stand consisted of an injection moulding machine, a strength testing machine, a hardness tester (durometer), a Charpy device, a plastometer and a shredder.

Tests were conducted using an Ergotech pro 25-80 single-screw injection moulding machine (Fig. 1) from Demag Mannesmann GmbH which is the property of the Faculty of Mechanical Engineering at the University of Technology in Košice. The injection moulding machine has a cylindrical screw with a diameter of $18 \mathrm{~mm}$ and a length to diameter ratio $L / D=20$. The plasticizing system of the Demag injection moulding machine has four heating zones of an equal length and allows a shot of up to $28 \mathrm{~cm}^{3}$ of plasticized material to be injected into the moulding cavity at a pressure of up to $274 \mathrm{MPa}$.

The injection moulding machine can exert a closure force of $250 \mathrm{kN}$. An injection mould assembly composed of two parts is fixed to the platens of the clamping unit. One part (the cavity side) has a flow system of channels comprising a sprue, runners, and gates as well as two mould cavities with a shape and dimensions corresponding to normalized strength test samples (Fig. 2). The other part (the core side) is a flat plate which slides to close the first part. The mould is thermostated with oil at $40{ }^{\circ} \mathrm{C}$ which circulates in channels integrated into the mould design.

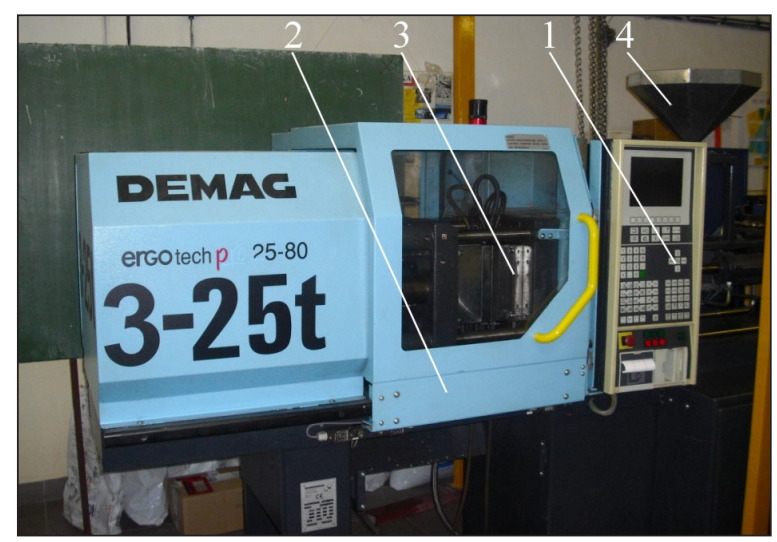

Fig. 1. View of the Demag Ergotech pro 25-80 injection moulding machine used in the study: 1 - control panel, 2 - tool assembly housing 3 -injection mould, 4 - hopper 


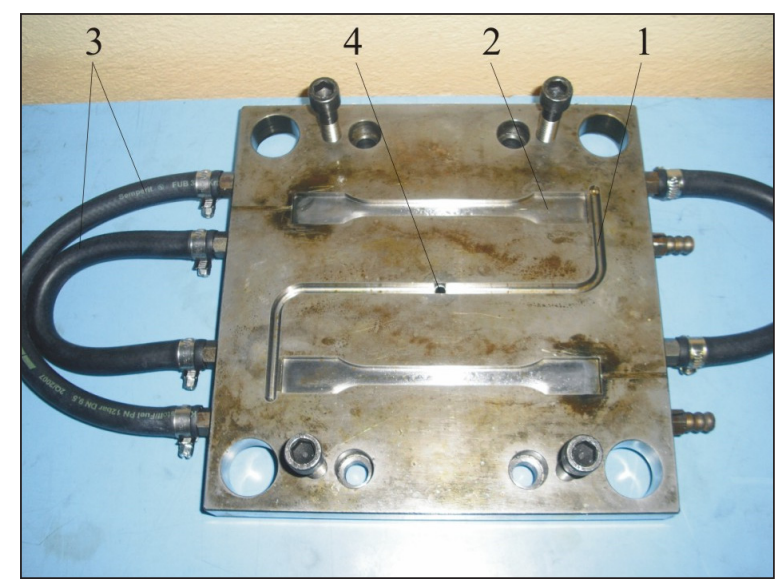

Fig. 2. A view of the mould used in the study: 1 - runner, 2 - mould cavity, 3 - cooling channels, 4 - sprue

Static tensile strength tests of normalized injection moulded hybrid strength test specimens obtained from polypropylene with different contents of a metallic powder filler were carried out using a standard Tira-test 2300 tensile tester from Tira $\mathrm{GmbH}$ with a tensile force measurement range of 0 to $10 \mathrm{kN}$; the accuracy of measurement of tensile force was $1 \mathrm{~N}$ and the tensile speed was $100 \mathrm{~mm} / \mathrm{min}$.

Shore hardness tests were carried out using a Shore D-scale durometer from Affri (Italy) at a measurement time of 15 seconds.

Impact strength was determined using a 639 F Charpy test apparatus from Cometech Testing Machines Co., Ltd. The tests were conducted using a hammer with an impact energy of $5 \mathrm{~J}$.

The stand for mass flow rate testing was equipped with an XRL-400 melt flow indexer (extrusion plastometer) fitted out with accessories and a laboratory balance PS $210 / \mathrm{C} / 2$ (measuring range, 0-210 g; measurement accuracy, $0.001 \mathrm{~g}$ ). The tests were carried out at 15 -s cut-off intervals at a temperature of 230 and a load of $2.16 \mathrm{~kg}$.

The polymer was shredded using a Rapid $2 \mathrm{a}$ blade shredder. This device is equipped with two adjustable, fixed vertical blades attached to the housing of the shredding chamber and two vertical moving blades mounted on the rotor directly driven by a $3 \mathrm{~kW}$ motor with a rotational speed of $1410 \mathrm{rpm}$. The shredding chamber has a sieve collar, the surface of which represents $40 \%$ of the surface area of the walls of the chamber. It has 102 holes with a diameter of $6 \mathrm{~mm}$ arranged in parallel in six rows, 17 holes each; the minimum distance between the edges of the holes in a row and between the rows is $7.5 \mathrm{~mm}$. The total surface area of the openings is $2.880 \mathrm{~mm}^{2}$, which constitutes $15 \%$ of the total surface area of the sieve.

\section{MEASUREMENT TECHNIQUE}

Each heating section of the plasticizing system of the injection moulding machine was heated to a preset temperature so as to achieve an appropriate temperature distribution along the length of the plasticizing unit. When the temperature had been stabilized, after approximately one hour of heating up, further parameters of the injection moulding process were set to remain constant throughout the process.

The polymer was introduced into the hopper of the injection moulding machine, and injection moulding cycles were run until the plastic was used up. Then, 10 moulded specimens were put away and the remaining ones were crushed in the blade shredder. The shredded polymer was once again introduced into the hopper of the injection moulding machine, and injection moulding cycles were performed until all the material was used. Injection moulded specimens were put away and the rest were crushed in the blade shredder. The procedure was repeated 14 times.

After 48 hours, the specimens were measured to establish their longitudinal and transverse dimensions, and then their hardness, impact strength, static tensile strength and melt mass flow rate were determined. The results were expressed as an arithmetic mean of five measurements.

Tensile testing of polypropylene specimens obtained in the injection moulding process was carried out in accordance with the standard PNEN ISO 527-1:1998. The hardness of specimens was determined according to PN-EN ISO 868: 2005. Charpy impact strength was measured according to PN-EN ISO 179-1: 2010. The melt mass flow rate was calculated using PN-EN ISO 1133-1: 2011.

In all cases, the final result was an arithmetic mean of five measurements.

\section{RESULTS}

The results were presented graphically as plots of the number of processing cycles as a function of the following variables: Young's modulus E, maximum tensile stress $\sigma_{\mathrm{z}}$ and breaking stress $\sigma_{\mathrm{r}}$, as well as strain at maximum stress $\varepsilon_{\mathrm{z}}$ and strain at break $\varepsilon_{\mathrm{r}}$. The figures below show 


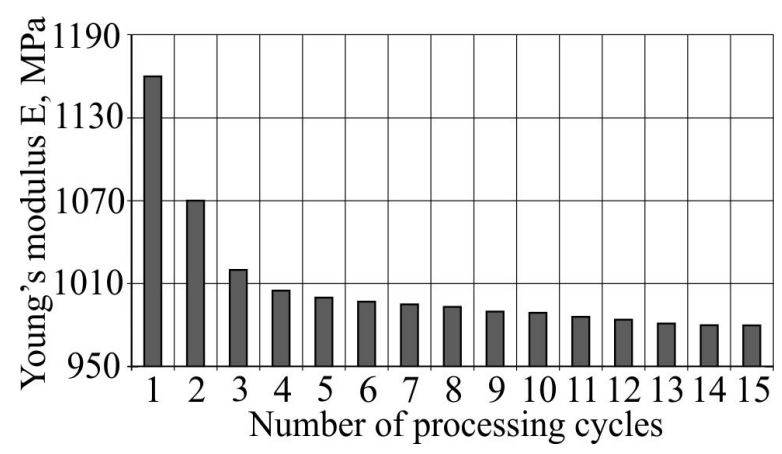

Fig. 3. The relationship between Young's modulus E and the number of processing cycles

the relationships between the number of processing cycles and the following parameters: Young's modulus E (Fig. 3), maximum tensile stress $\sigma_{\mathrm{z}}$ (Fig. 4), breaking stress $\sigma_{\mathrm{r}}$ (Fig. 5), strain at maximum stress $\varepsilon_{\mathrm{z}}$ (Fig. 6) and strain at break $\varepsilon_{\mathrm{r}}$ (Fig. 7) for the injection moulded polypropylene products obtained in the experiment.

Multiple processing of Morplen RP2380 resulted in a significant decrease in Young's modulus (Fig. 3), the value of which decreased from 1,160 MPa to $980 \mathrm{MPa}$ after fifteen processing cycles, that is by more than $15.5 \%$. It has to be noted, however, that the decrease was quite rapid up to the fourth injection cycle, and the subsequent cycles did not cause such substantial changes in the investigated characteristic of the polypropylene. The first four processing cycles led to an over $13.3 \%$ reduction in Young's modulus of the test polymer, while processing cycles five to fifteen lowered the value of that parameter only by less than $2.5 \%$.

A similarly shaped graph was obtained for tensile strength as a function of number of polypropylene processing cycles (Fig. 4). The overall decline in tensile strength over the investigated range of number of processing cycles was 2.8

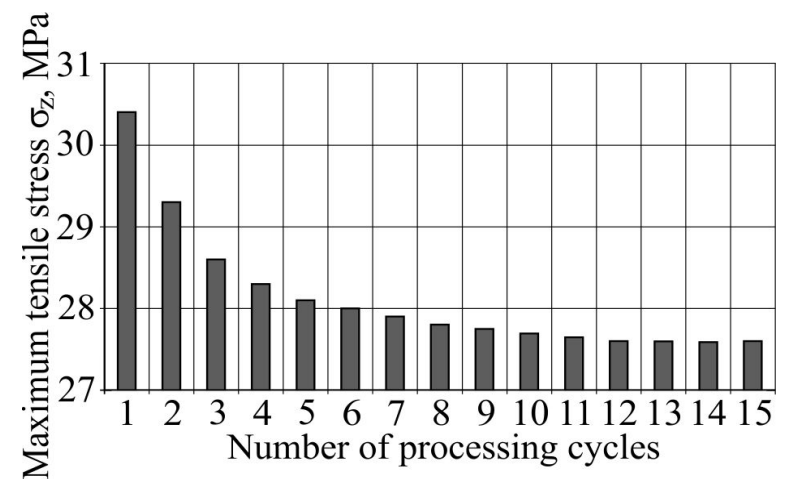

Fig. 4. The relationship between maximum tensile stress $\sigma_{\mathrm{z}}$ and the number of processing cycles

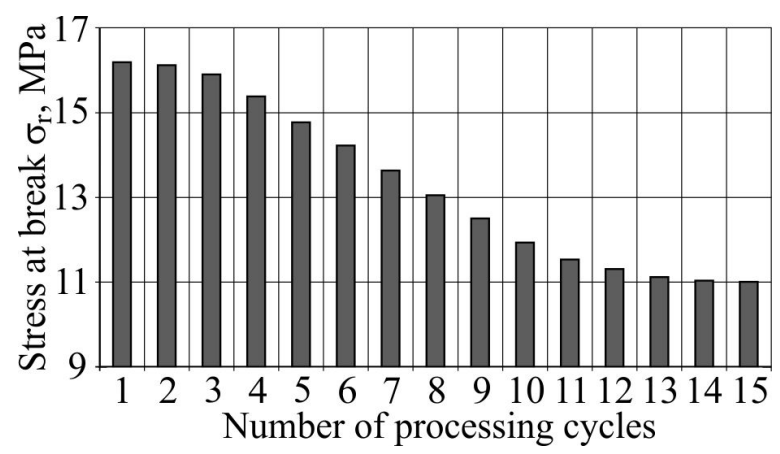

Fig. 5. The relationship between stress at break $\sigma_{\mathrm{r}}$ and the number of processing cycles

$\mathrm{MPa}$, i.e. 9.2\%. As in the previous case, there were two regions of change which differed in the intensity of reduction of the test parameter. In the first region, up to the sixth, seventh processing cycle, tensile strength decreased by $2.5 \mathrm{MPa}$, whereas in the second region, up to the fifteenth processing cycle, it decreased by only $0.3 \mathrm{MPa}$.

In turn, the graph of stress at break as a function of number of polypropylene processing cycles could be divided into three regions related to the intensity of change of the test variable (Fig. $5)$. The first one encompassed the first three processing cycles, in which stress at break of the polypropylene being processed remained practically unchanged at $16 \mathrm{MPa}$; the second region corresponded to the further nine processing cycles, in which the decrease in stress at break was proportional to the number of processing cycles. The third change range included the last three processing cycles, in which, similarly to the first region, the value of stress at break did not change. The overall decrease in stress at break was 5.18 $\mathrm{MPa}$, i.e. nearly $32 \%$.

The graphs of strain at maximum tensile stress (Fig. 6) and strain at break (Fig. 7) as a function of number of processing cycles of the test mate-

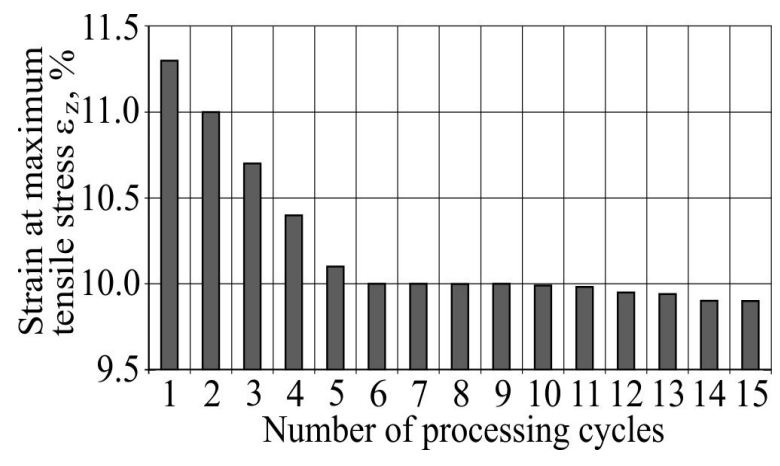

Fig. 6. The relationship between strain at maximum tensile stress $\varepsilon_{\mathrm{z}}$ and the number of processing cycles 


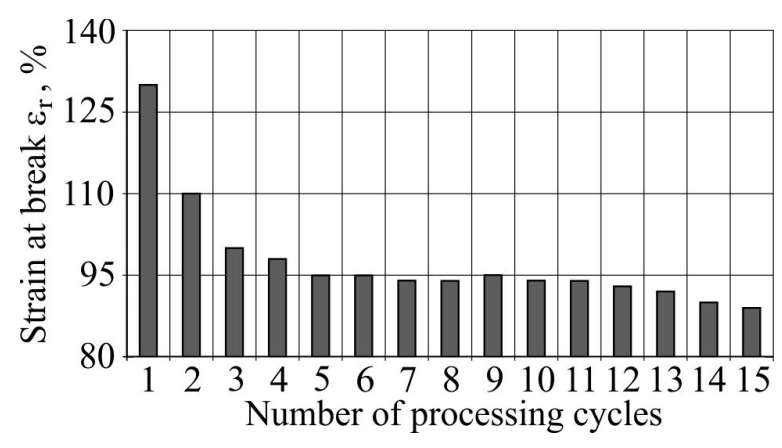

Fig. 7. The relationship between strain at break $\varepsilon_{\mathrm{r}}$ and the number of processing cycles

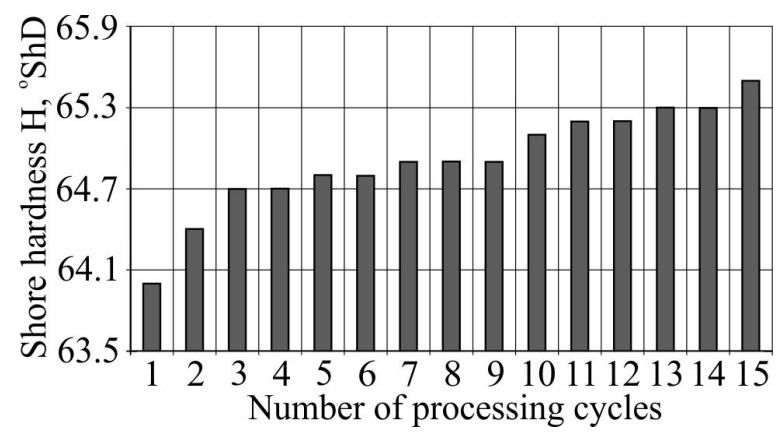

Fig. 8. The relationship between D-scale Shore hardness $\mathrm{H}$ and the number of processing cycles for the tested polypropylene

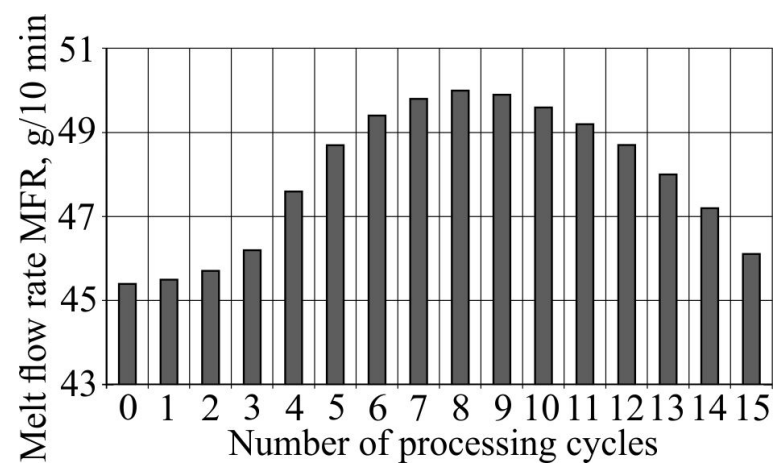

Fig. 9. The relationship between melt flow rate MFR of the tested polypropylene and the number of processing cycles

rial are similar in nature. The overall decline is $13.4 \%$ in the first one and $31.3 \%$ in the second. The area of the most intense decline in strain at maximum stress corresponds to the first five processing cycles, and in the case of strain at break, it encompasses the first three cycles, with further processing cycles not causing any significant changes in the examined parameters.

A D-scale Shore durometer was used to determine the impact of multiple processing on the hardness of the moulded products obtained in the study. Figure 8 presents the relationship between Shore hardness and the number of processing cycles the polypropylene was subjected to. As the number of injection cycles increased, the hardness of the injection moulded parts grew slightly, but the increase after 15 cycles was only a little more than $2.3 \%$, which was close to a potential error.

The relationship between polypropylene melt mass flow rate and the number of injection cycles is shown in Fig. 9. An initial increase in mass flow rate was followed by a decline. MFR for the virgin plastic was not fundamentally different from MFR determined after the first processing cycle; a slightly greater increase was observed only after the third processing cycle. The value of MFR increased up to the eighth processing cycle, with subsequent cycles causing a slow decrease in mass flow rate. The initial increase to $50 \mathrm{~g} / 10 \mathrm{~min}$, which was more than $10.1 \%$ of the initial value, was followed by a $7.8 \%$ reduction to $3.9 \mathrm{~g} / 10 \mathrm{~min}$.

The length and width of the obtained injection moulded products were measured and compared with corresponding dimensions of the moulding cavity of the injection mould in order to determine the impact of multiple processing on longitudinal and transverse shrinkage of the products. Longitudinal and transverse shrinkage were calculated from the formula:

$$
\mathrm{S}=\left[\left(\mathrm{L}_{0}-\mathrm{L}_{1}\right) / \mathrm{L}_{0}\right] \cdot 100 \%
$$

where: $\mathrm{L}_{0}$ - stands for the dimensions of the mould cavity,

$\mathrm{L}_{1}$ - represents the corresponding size of the resulting part obtained in this cavity.

Figure 10b shows longitudinal shrinkage calculated according to this formula. The results of measurements of the longitudinal dimension of the obtained propylene injection mouldings as a function of number of processing cycles are shown in Figure 10a.

The longitudinal shrinkage of an injection moulded part made from virgin polypropylene was $1.48 \%$ and was the lowest in the tested range of number of processing cycles. Re-processing of this PP led to a $0.14 \%$ up to $1.64 \%$ increase in shrinkage, which was more than $9.4 \%$ of the initial value. Further processing cycles did not cause such a large increase in longitudinal shrinkage, which was maintained at above $1.65 \%$. 
a)

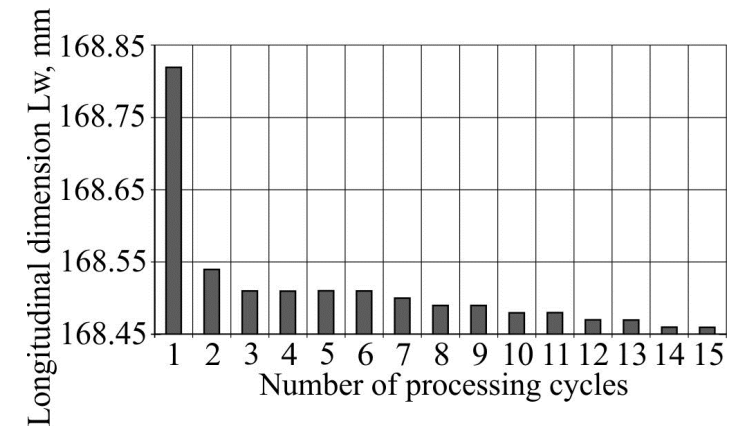

b)

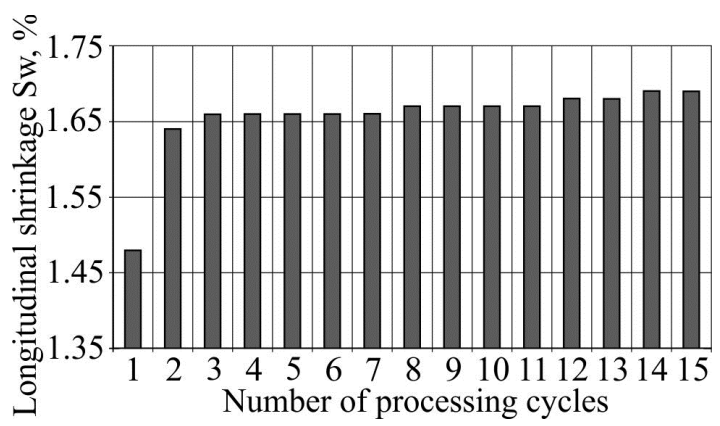

Fig. 10. Bar graphs of a) longitudinal dimension $\mathrm{L}_{\mathrm{w}}$ and $\mathrm{b}$ ) longitudinal shrinkage $\mathrm{S}_{\mathrm{w}}$ of an injection moulded part vs. number of processing cycles

The results of measurements of the longitudinal dimension of the obtained propylene injection mouldings as a function of number of processing cycles are shown in Figure 11a, whereas Figure $11 \mathrm{~b}$ presents the relationship between transverse shrinkage and the number of PP injection cycles. As in the case of longitudinal shrinkage, the smallest shrinkage value of 3.09\% was recorded for the first PP processing cycle; re-processing of the test polymer increased shrinkage to $3.19 \%$, and further re-processing resulted in a further increase in transverse shrinkage values to $3.28 \%$, which was over $3.2 \%$ and over $6.1 \%$ of the shrinkage values recorded after the first processing cycle, respectively. The fourth cycle led to an increase in transverse shrinkage to a value of $3.33 \%$, which remained unchanged over the next four cycles. Transverse shrinkage increased again after the ninth cycle. Longitudinal shrinkage of the injection mouldings obtained from polypropylene after multiple processing cycles was two times smaller than transverse shrinkage.

\section{CONCLUSIONS}

The results of the tests conducted in this study on the effect of multiple processing of a propyl- ene on its properties demonstrated that multiple injection moulding of a thermoplastic such as Moplen RP2380 is not without an effect on the mechanical and processing properties of the polymer. The mechanical properties of the polypropylene (Young's modulus, maximum tensile stress, breaking stress, strain at maximum stress and strain at break) determined in a static tensile strength test after multiple processing cycles deteriorated with the growing number of injection cycles by several to several dozen percent. The hardness of the polypropylene remained almost constant over the injection cycles but showed a tendency to increase.

The largest deterioration of the investigated strength properties was observed for the polymer which had been processed two-, three- and four times; further processing did not lead to such a pronounced decrease in these properties.

The mass flow rate of the polypropylene which was undergoing multiple processing cycles decreased after an initial increase. The highest MFR was obtained after the eighth cycle, and then dropped but was still higher after the fifteenth cycle than after the first cycle.

The longitudinal and transverse shrinkage increased with the growing number of polypropylene processing cycles, with transverse shrinkage being twice as large as longitudinal shrinkage.

a)

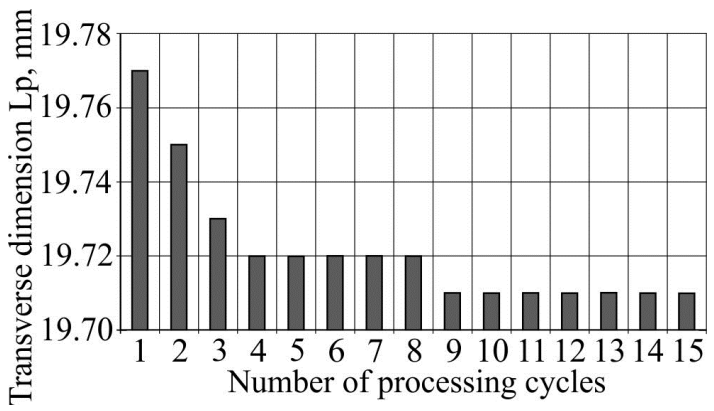

b)

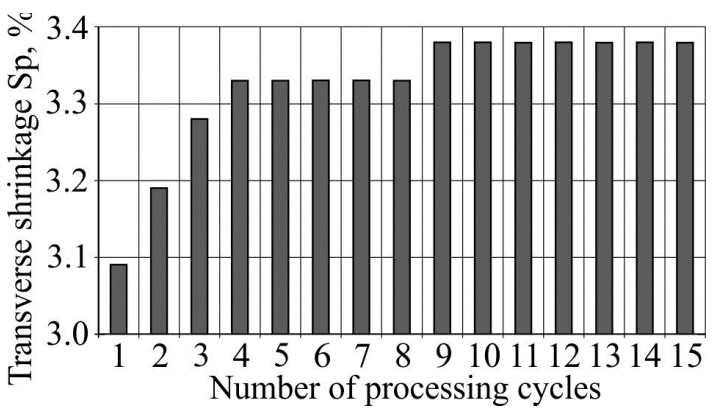

Fig. 11. Graph bars of a) transverse dimension $\mathrm{L}_{\mathrm{p}}$ and b) transverse shrinkage $S_{p}$ of an injection moulded part vs. number of processing cycles 


\section{Acknowledgements}

The authors wish to thank the Slovak Academic Information Agency for their organizational and financial support of this study within the framework of the National Scholarship Programme for the Support of Mobility of University Students, PhD Students, University Teachers, Researchers and Artists in 2015 and VEGA 1/0600/13.

\section{REFERENCES}

1. Bociąga E., Magaczewski P., Wpływ wielokrotnego przetwarzania tworzyw ABS oraz PP na ich właściwości reologiczne i przetwórcze. Przetwórstwo Tworzyw, 12 (2), 2006, 45-52.

2. Costa H.M., Ramos V.D., Rocha M. C.G., Rheological properties of polypropylene during multiple extrusion. Polymer Testing, 24 (1), 2005, 86-93.

3. Costa H.M., Ramosa V.D., Oliveira M.G., Degradation of polypropylene (PP) during multiple extrusions: Thermal analysis, mechanical properties and analysis of variance. Polymer Testing, 26 (5), 2007, 676-684.

4. Czarnecka-Komorowska D., Recykling niskoudarowego polistyrenu (GPPS): struktura, właściwości. Przetwórstwo Tworzyw, 19 (5), 2013, 485-489.

5. Dulebová L., Greškovič F., The influence of amount of filler on mechanical properties for electro products. Scientific Papers of University of Rzeszow: Zeszyty Naukowe Politechniki Rzeszowskiej: Mechanika, 273, 2010, 59-64.

6. Garbacz T., Dulebová L., Krasinskyi V.: Effectiveness of cellurar injection molding process. Advances in Science and Technology: Research Journal, 7 (18), 2013, 74-80.

7. Jachowicz T. and Gajdoš I. Effect of natural ageing on some properties of oxybiodegrading agent-containing polypropylene products. Przemysl Chemiczny, 93(11), 2014, 1983-1985.

8. Jakubowska P., Kloziński A., Wpływ temperatury na właściwości wytrzymałościowe mieszanin polimerowych PP/PS w funkcji krotności przetwórs- twa. Inżynieria i Aparatura Chemiczna, 49 (5), 2010, 47-48.

9. Kijeński J., Polaczek J., Recykling odpadów tworzyw sztucznych w Polsce. Wczoraj, dziś, jutro. Inżynieria Materiałowa, 1, 2005, 40-44.

10. Kloziński A., Jakubowska P., Sterzyński T., Ocena właściwości przetwórczych mieszaniny PP/PS w aspekcie krotności. Inżynieria i Aparatura Chemiczna, 15 (5), 2008, 15-16.

11. Lozano-González M.A.J, Rodriguez-Hernandez M.A.T., Gonzalez-De Los Santos E.A., Villalpando-Olmos J., Physical-mechanical properties and morphological study on nylon-6 recycling by injection molding. Journal of Applied Polymer Science, 76 (6), 2000, 851-858.

12. Richert J., Żenkiewicz M., Richert A., Malinowski R., Wpływ trzykrotnego wytłaczania nanokompozytu polietylenowego na niektóre właściwości granulatu, kształtek i folii. Przetwórstwo tworzyw, 16 (4), 2010, 188-191.

13. Rydzkowski T., Michalska-Pożoga I., Zmiany barwy podczas wielokrotnego wytłaczania PELD. Przetwórstwo tworzyw, 18 (6), 2012, 637-641.

14. Samujło B., Kowalska B., Rudawska A., Kloziński A., Wybrane właściwości mechaniczne polipropylenu wielokrotnie przetwarzanego. Zeszyty Naukowe Politechniki Rzeszowskiej. Chemia, 20, 2009, 127-130.

15. Samujło B., Wpływ wielokrotnego przetwórstwa na palność polipropylenu. Przetwórstwo tworzyw, 16 (4), 2010, 199-201.

16. Sikora R. and Jachowicz T.: Wpływ czasu ochładzania na skurcz przetwórczy wytworów otrzymanych metodą wytłaczania $\mathrm{z}$ rozdmuchiwaniem. Polimery, 45 (10), 2000, 713-719.

17. Su K.H., Lin J.H., Lin C.C., Influence of reprocessing on the mechanical properties and structure of polyamide 6. Journal of Materials Processing Technology 192-193, 2007, 532-538.

18. Szostak M., Wpływ krotności przetwarzania mieszanin PET/PEN na ich właściwości mechaniczne i cieplne. Inżynieria i aparatura chemiczna, 49 (5), 2010, 115-116.

19. Urbaniak W., Problemy recyklingu opakowań z tworzyw sztucznych. Recykling, 9, 2004, 38-38. 